\title{
Religious/spiritual coping in informal caregivers of children with cleft lip and/or dysphagic palate
}

\author{
Coping religioso/espiritual em cuidadores informais de crianças com fissura de lábio e/ou palato disfágicas \\ Coping religioso/espiritual en cuidadores informales de niños con labio leporino y/o fisura del paladar
}

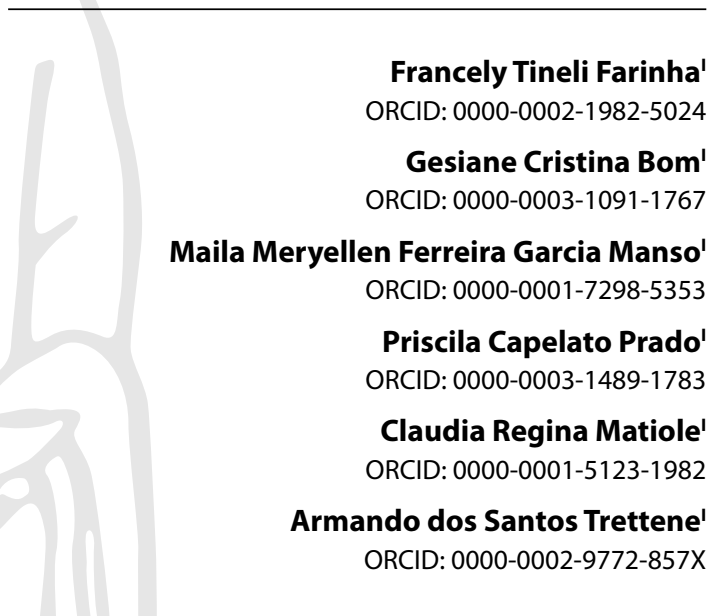

'Universidade de São Paulo, Hospital de Reabilitação de Anomalias Craniofaciais. Bauru, São Paulo, Brazil.

How to cite this article: Farinha FT, Bom GC, Manso MMFG, Prado PC, Matiole CR, Trettene AS. Religious/spiritual coping in informal caregivers of children with cleft lip and/or dysphagic palate. Rev Bras Enferm. 2022;75(Suppl 2):e20201300. https://doi.org/10.1590/0034-7167-2020-1300

\section{Corresponding author: \\ Francely Tineli Farinha \\ E-mail: francelyfarinha@usp.br}

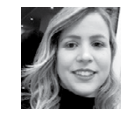

EDITOR IN CHIEF: Antonio José de Almeida Filho ASSOCIATE EDITOR: Mitzy Danski

Submission: $01-11-2021$

Approval: 07-02-2021

\begin{abstract}
Objectives: to identify the use of religious/spiritual coping in informal caregivers of children with cleft lip and/or palate, dysphagic, powered exclusively by probe. Methods: descriptive and cross-sectional study, including 30 informal caregivers. For data collection, a Sociodemographic Questionnaire and the Brief Religious/Spiritual Coping Scale were used. For statistical analysis, ANOVA, Student's t and Spearman's correlation tests were used, with a significance level of $5 \%$. Results: the use of religious/spiritual coping was high among participants (mean=3.71), with a predominance of positive (mean=3.30) compared to negative (mean=1.88). It was evident that the greater the reported importance of religiosity/spirituality in the participants' lives, the greater the positive coping $(p=0.001)$. Conclusions: informal caregivers used positive religious/spiritual coping as a way of coping with care demands related to the child's health condition. These findings point to the importance of including spirituality/religiosity as health indicators.

Descriptors: Caregivers; Cleft Lip; Cleft Palate; Spirituality; Religion.
\end{abstract}

\section{RESUMO}

Objetivos: identificar o uso do coping religioso/espiritual em cuidadores informais de crianças com fissura de lábio e/ou palato, disfágicas, alimentadas exclusivamente por sonda. Métodos: estudo descritivo e transversal, incluindo 30 cuidadores informais. Para a coleta de dados, utilizou-se um Questionário Sociodemográfico e a Escala de Coping Religioso/ Espiritual Breve. Para a análise estatística, utilizaram-se os testes de ANOVA, $t$ de Student e a correlação de Spearman, com nível de significância de 5\%. Resultados: o uso do coping religioso/espiritual foi alto entre os participantes (média=3,71), com predomínio do positivo (média=3,30) comparado ao negativo (média $=1,88$ ). Evidenciou-se que, quanto maior a importância relatada da religiosidade/espiritualidade na vida dos participantes, maior foi o coping positivo $(p=0,001)$. Conclusões: os cuidadores informais utilizaram o coping religioso/espiritual positivo como modalidade de enfrentamento das demandas de cuidados relacionadas à condição de saúde da criança. Esses achados apontam a importância de incluir a espiritualidade/religiosidade como indicadores de saúde.

Descritores: Cuidadores; Fenda Labial; Fissura Palatina; Espiritualidade; Religião.

\section{RESUMEN}

Objetivos: identificar el uso del coping religioso/espiritual en cuidadores informales de niños con labio leporino y/o fisura del paladar alimentado exclusivamente por sonda. Métodos: estudio descriptivo y transversal, incluyendo 30 cuidadores informales. La recolecta de datos, se utilizó una Encuesta Sociodemográfica y Escala de Coping Religioso/Espiritual Breve. Para el análisis estadístico, se utilizaron los test de ANOVA, $t$ de Student y correlación de Spearman, con nivel de significación de $5 \%$. Resultados: uso del coping religioso/espiritual fue alto entre los participantes (mediana $=3,71$ ), con predominio del positivo (mediana $=3,30$ ) comparado al negativo (mediana $=1,88$ ). Evidenciado que, cuanto mayor la importancia relatada de la religiosidad/espiritualidad en la vida de los participantes, mayor fue el coping positivo $(p=0,001)$. Conclusiones: los cuidadores informales utilizaron el coping religioso/espiritual positivo como modalidad de enfrentamiento de demandas de cuidados relacionadas a condición de salud del niño. Esos hallados apuntan la importancia de incluir la espiritualidad/ religiosidad como indicadores de salud.

Descriptores: Cuidadores; Labio Leporino; Fisura del Paladar; Espiritualidad; Religión. 


\section{INTRODUCTION}

Cleft lip and/or palate stand out among the malformations that affect the face, with a prevalence of 1:700 births. It has a multifactorial etiology, including genetic and environmental factors. They may present in isolation or in association with syndromes and/or other malformations ${ }^{(1)}$.

Associated syndromes include the Pierre Robin Sequence, Stickler, Treacher Collins, Van der Woude, among others ${ }^{(1)}$. In these specific cases, the functional aspects may be compromised, including feeding, that is, these children usually evolve with oropharyngeal dysphagia, in which the act of eating orally will be compromised ${ }^{(2)}$.

With this, feeding becomes a risky and frustrating process, both for the child and for their parents and/or caregivers, that is, a chronic condition. In these cases, feeding tubes are often used, which make feeding viable and significantly contribute to these children's having a favorable clinical condition ${ }^{(2-3)}$.

In the demand for the care of dysphagic children and those using a feeding tube, the continuous need for supine positioning, preparation and administration of the diet, maintenance of permeability and adequate fixation of the tube, nasal and oral hygiene, and continuous attention to signs and symptoms of complications such as nausea, vomiting, diarrhea, reflux, among others ${ }^{(4)}$.

Faced with this reality, often parents or family members, especially mothers, assume the role of main caregivers. Because they are not health professionals, that is, because they do not have technical-scientific knowledge to do so, they are called "informal caregivers"(2).

Although they receive training during the child's hospitalization regarding the necessary care, in order to guarantee continuity at home, the routine after hospital discharge, in view of this new reality, becomes extremely exhaustive ${ }^{(2,5-6)}$. In fact, these informal caregivers experience numerous psychosocial repercussions, such as overload, stress, negative impact on family and social life, among others ${ }^{(7)}$.

Thus, the demand for care linked to the diagnosis of a chronic situation can lead to drastic physical and emotional symptoms, which may negatively influence behavior and adaptation, also affecting the quality of care provided ${ }^{(8-9)}$.

Thus, adaptations are needed so that they experience this period in a less painful way, that is, it is necessary to establish or develop modalities of situational coping, referred to as coping. In other words, the difference will be the way in which these informal caregivers will provide resources and mobilize efforts to face this situation, aiming to reduce or minimize negative outcomes ${ }^{(10)}$.

The experience of a chronic situation, the deficit of emotional, financial and psychosocial support, associated with the difficulty of acceptance and the search to reframe or make sense of the situation experienced, contribute to people seeking answers or support in transcendent aspects, including religious and/or spiritual $^{(10)}$.

In this sense, the religious-spiritual coping (CRE) emerges, which refers to the religious beliefs and behaviors experienced by people in order to facilitate the resolution of problems and/ or prevent or alleviate negative emotional consequences in the face of stressful situations. It can be presented in two ways: positive or negative ${ }^{(10-11)}$.

The positive is characterized by beneficial effects that include seeking love, protecting God, connecting with higher forces, seeking help, finding comfort in religious literature, forgiveness, prayer, and God's help in facing life's difficulties. On the other hand, the negative generates harmful effects, which include questioning the very existence and love of God, blaming God for the problems experienced, interpreting them as divine punishment, feelings of dissatisfaction and discontent with God and with members of the religion, among others ${ }^{(10-11)}$.

Several investigations have demonstrated the growing use of CRE by informal caregivers, including children, the elderly, people with mental problems, cancer patients and trauma victims $s^{(12-15)}$. It is important to emphasize that the use of positive CRE is related to better outcomes in physical and mental health ${ }^{(16)}$. On the other hand, it is evident that the use of negative CRE can trigger depressive symptoms, health problems and a worse perception of quality of life ${ }^{(12-17)}$.

In short, it is important to identify how informal caregivers have used the RSC. Thus, we sought to answer the following questions: Do informal caregivers of children with cleft lip and/ or palate, dysphagia and using a feeding tube use the CRE? Do they predominantly use positive or negative CRE?

Although studies on CRE among informal caregivers are available, no research was found with the population of this study in the consulted databases, pointing out the relevance of this investigation with an unprecedented approach.

\section{OBJECTIVES}

To identify the use of CRE in informal caregivers of children with cleft lip and/or palate, dysphagia, powered exclusively by probe.

\section{METHODS}

\section{Ethical aspects}

All precepts of Resolution 466/12 of the National Health Council on research involving human beings were complied with. The Research Ethics Committee of the institution that was the setting for this investigation, gave a favorable opinion on the study, and the participants signed the Informed Consent Form.

\section{Study design, period and place}

Descriptive, cross-sectional study with a quantitative design, guided by the STROBE tool.

It was developed between May 2019 and January 2020 in a public hospital, tertiary care, located in the city of Bauru, state of São Paulo (SP), Brazil. It is an institution specialized in the treatment of patients with craniofacial anomalies and related syndromes, recognized nationally and internationally for its interdisciplinary and humanized care in the areas of care, teaching and research.

Population or sample; inclusion and exclusion criteria 
The population consisted of informal caregivers of children diagnosed with cleft lip and/or palate and dysphagia and who were admitted to the Semi-Intensive Care Unit during the period stipulated for data collection.

Sampling was consecutive and not probabilistic. For sample size calculation, a pilot study was carried out, whose standard deviation was 0.5 point. Based on this, a maximum sampling error of 0.2 and a confidence level of $95 \%$ were considered. With this, 25 participants were estimated. Finally, the sample had 30 participants.

The following inclusion criteria were established: being informal primary caregiver, being 18 years old or older, of children aged between zero and 1 year, 11 months and 29 days, and who were fed exclusively through a tube. Informal caregivers who used psychotropic drugs and/or cared for children with neuropsychomotor impairment were excluded.

\section{Study protocol}

Initially, there was an invitation to join the research, where the objectives and instruments used in data collection were presented. This was carried out individually and in a private place, with an average duration of 30 minutes.

Two instruments were used: Sociodemographic Questionnaire and the Brief Religious-Spiritual Coping Scale (CRE-Breve) ${ }^{(11)}$. The Sociodemographic Questionnaire was applied through an interview with the participant to collect the following variables: sex, age, religion, education, number of children, marital status and occupation. And for the collection of the variable"socioeconomic classification", medical records were consulted.

To assess the CRE, the CRE-Breve Scale was used, which was developed based on the North American scale Rcope Scale - Spiritual/Religious Coping Scale, translated, adapted and validated for the Brazilian culture. It consists of 49 items that are grouped into 11 factors, 7 related to positive CRE (CREP - 34 items) and 4 factors related to negative CRE (CREN - 15 items) ${ }^{(11,18)}$.

To identify the stressful stimulus that led to the need for coping through the RSC, the instrument presents a descriptive question in which a brief report is requested regarding the greatest stress experienced in the last three years. For this study, this descriptive question focused on the stress experienced by the participants in relation to the demand for care for the child with cleft lip and/ or palate, dysphagia and using a feeding tube. In short, the scale seeks to identify the positive and negative strategies of religious/ spiritual coping ${ }^{(11)}$.

The answers are given on a Likert-type scale, ranging from 1 to 5, where a score of 1.00 means "not at all"; and 5.00, "very

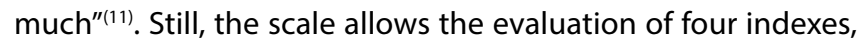
namely: the CREP referring to the positive religious/spiritual coping performed by the person; the CREN related to the negative religious/spiritual coping performed by the individual; the total $\mathrm{CRE}$, which indicates the total number of religious/spiritual coping strategies mobilized by the person to cope with the stressful stimulus; and the CREN/CREP Ratio, which reveals the percentage of CREN used in the total CREP. In this index, the value is between 0.20 and 5.00, in which, the lower this value, the greater will be the use of CREP in relation to CREN; and the higher, the greater will be the use of CREN in relation to the use of CREP ${ }^{(11,18)}$.

\section{Analysis of results and statistics}

Data were analyzed using the IBM Statistical Package for the Social Sciences software, version 21.0 for Windows. For categorical data, descriptive statistical analysis was used.

In order to correlate CREP, CREN and total CRE with sociodemographic variables (education, socioeconomic class, age, number of children, marital status and frequency of religious activities), Spearman's correlation coefficient was used. To correlate CREP, CREN and total CRE with the variables "marital status" and "religion", the ANOVA test was used. In the correlation of CREP, CREN and total CRE with the referred importance of religion/spirituality, Student's t test was used. The significance level adopted for all tests was $5 \%(p \leq 0.05)$.

\section{RESULTS}

The sample consisted of 30 mothers, whose mean age was 31.97 years $(S D=8.64)$. Those who were married and/or in a stable relationship prevailed $(90 \% ; n=27)$, with complete high school $(46.7 \% ; n=14)$, without employment $(60 \% ; n=18)$, with an only child $(36.7 \% ; n=11)$ and belonging to the upper low socioeconomic class $(50 \% ; n=15)$.

Regarding religion, the majority $(46.7 \% ; n=14)$ declared themselves evangelical. As for the frequency with which they participated in religious/spiritual activities, 36.7\% $(n=11)$ answered "one or more times a week". They also stated that they considered religiosity/spirituality as very important in their lives (86.7\%; $n=26)$.

It was evident that the use of CRE was high among the participants (Mean $=3.71 ; \mathrm{SD}=0.44$ ). It was also observed a greater use of CREP (Average $=3.30 ; \mathrm{SD}=0.48$ ) compared to CREN (Average $=1.88$; $\mathrm{SD}=0.76$ ), which is confirmed by the CREN/CREP ratio, which had a mean of $0.57(S D=0.24)$, as shown in Table 1 .

The factor that had a high influence on the use of CREP was "positive position before God" (Average $=4.71$; SD $=0.45$ ); and low influence, "search for spiritual knowledge" (Average $=2.11$; $S D=0.89$ ). In relation to $C R E N$, the factor that had the greatest influence was "negative position before God" (Average $=2.54$; SD =1.28); and little influence, "dissatisfaction with the institutional other" (Average $=1.52 ; \mathrm{SD}=0.75)$ (Table 2).

Table 1 - Analysis of religious/spiritual coping, Bauru, São Paulo, Brazil, 2020

\begin{tabular}{|c|c|c|c|c|c|c|c|}
\hline Variables & Mean & Standard deviation & Maximum value & Minimum value & Median & Q1* & Q3 $^{*}$ \\
\hline Total CRE* & 3.71 & 0.44 & 4.39 & 2.76 & 3.78 & 3.46 & 4.07 \\
\hline Positive CRE & 3.30 & 0.48 & 4.26 & 1.97 & 3.37 & 3.00 & 3.61 \\
\hline Negative CRE & 1.88 & 0.76 & 3.93 & 1.00 & 1.90 & 1.20 & 2.20 \\
\hline Ratio between negative and positive CRE & 0.57 & 0.24 & 1.13 & 0.26 & 0.54 & 0.38 & 0.71 \\
\hline
\end{tabular}


Table 2 - Analysis of positive and negative religious/spiritual coping factors, Bauru, São Paulo, Brazil, 2020

\begin{tabular}{|c|c|c|c|c|c|c|c|}
\hline Variables & Mean & Standard deviation & Maximum value & Minimum value & Median & Q1 ${ }^{*}$ & $\mathbf{Q 3}^{*}$ \\
\hline \multicolumn{8}{|l|}{ Positive CRE* } \\
\hline Transformation of themselves and/or their life & 3.59 & 0.74 & 4.77 & 1.66 & 3.77 & 3.11 & 4.11 \\
\hline Actions in search of spiritual help & 2.35 & 0.82 & 4.00 & 1.00 & 2.20 & 1.80 & 3.00 \\
\hline Offer to help another & 3.03 & 0.83 & 4.80 & 1.40 & 3.10 & 2.40 & 3.60 \\
\hline Positive position before God & 4.71 & 0.45 & 5.00 & 3.40 & 5.00 & 4.60 & 5.00 \\
\hline Search for the other institutional & 2.63 & 0.84 & 4.25 & 1.00 & 2.75 & 2.00 & 3.25 \\
\hline Separation from God/Religion/Spirituality & 4.29 & 0.77 & 5.00 & 2.00 & 4.33 & 4.00 & 5.00 \\
\hline Search for spiritual knowledge & 2.11 & 0.89 & 4.66 & 1.00 & 2.00 & 1.33 & 2.66 \\
\hline \multicolumn{8}{|l|}{$\mathrm{CRE}^{*}$ negative } \\
\hline negative revaluation of God & 1.77 & 1.06 & 5.00 & 1.00 & 1.30 & 1.00 & 2.20 \\
\hline negative position before God & 2.54 & 1.28 & 4.66 & 1.00 & 2.50 & 1.33 & 3.66 \\
\hline Dissatisfaction with the institutional other & 1.52 & 0.75 & 3.75 & 1.00 & 1.25 & 1.00 & 2.00 \\
\hline Negative reappraisal of meaning & 1.89 & 0.90 & 3.66 & 1.00 & 1.66 & 1.00 & 2.33 \\
\hline
\end{tabular}

Correlation values of total CRE, CREP and CREN were not significantly associated with the following variables: education, age, socioeconomic level, number of children, frequency with which the individual practices religious activities, religion and marital status.

Table 3 - Correlation between religious/spiritual coping and the variables "employment bond" and "importance of religiosity/spirituality", Bauru, São Paulo, Brazil, 2020

\begin{tabular}{|c|c|c|c|c|}
\hline Correlation variables & $\mathbf{n}$ & Mean & $\begin{array}{l}\text { Standard } \\
\text { deviation }\end{array}$ & $p$ value \\
\hline \multicolumn{5}{|l|}{ Total CRE* } \\
\hline \multicolumn{5}{|c|}{ Employment relationship } \\
\hline Yes & 12 & 3.89 & 0.41 & \multirow[t]{2}{*}{0.060} \\
\hline No & 18 & 3.58 & 0.42 & \\
\hline \multicolumn{5}{|c|}{$\begin{array}{l}\text { Importance of spirituality } \\
\text { and reliqiosity }\end{array}$} \\
\hline Very important & 26 & 3.72 & 0.44 & \multirow{2}{*}{0.644} \\
\hline Important & 4 & 3.61 & 0.45 & \\
\hline \multicolumn{5}{|l|}{ Positive CRE } \\
\hline Employment relation & & & & \multirow{3}{*}{0.094} \\
\hline Yes & 12 & 3.48 & 0.42 & \\
\hline No & 18 & 3.18 & 0.49 & \\
\hline \multicolumn{5}{|c|}{$\begin{array}{l}\text { Importance of spirituality } \\
\text { and religiosity }\end{array}$} \\
\hline Very important & 26 & 3.40 & 0.39 & \multirow{2}{*}{$0.001^{*}$} \\
\hline Important & 4 & 2.63 & 0.53 & \\
\hline \multicolumn{5}{|l|}{ Negative CRE } \\
\hline \multicolumn{5}{|c|}{ Employment relationship } \\
\hline Yes & 12 & 1.69 & 0.67 & \multirow[t]{2}{*}{0.274} \\
\hline No & 18 & 2.00 & 0.80 & \\
\hline \multicolumn{5}{|c|}{$\begin{array}{l}\text { Importance of spirituality } \\
\text { and religiosity }\end{array}$} \\
\hline Very important & 26 & 1.95 & 0.76 & \multirow[t]{2}{*}{0.183} \\
\hline Important & 4 & 1.40 & 0.67 & \\
\hline
\end{tabular}

Also, it was observed that the CREP, CREN and total CRE did not show a significant association with professional occupation. However, regarding the variable "religious importance", it was identified that the greater the importance of religiosity/spirituality in the participants' lives, the higher the CREP $(p=0.001)$ (Table 3 and Figure 1).

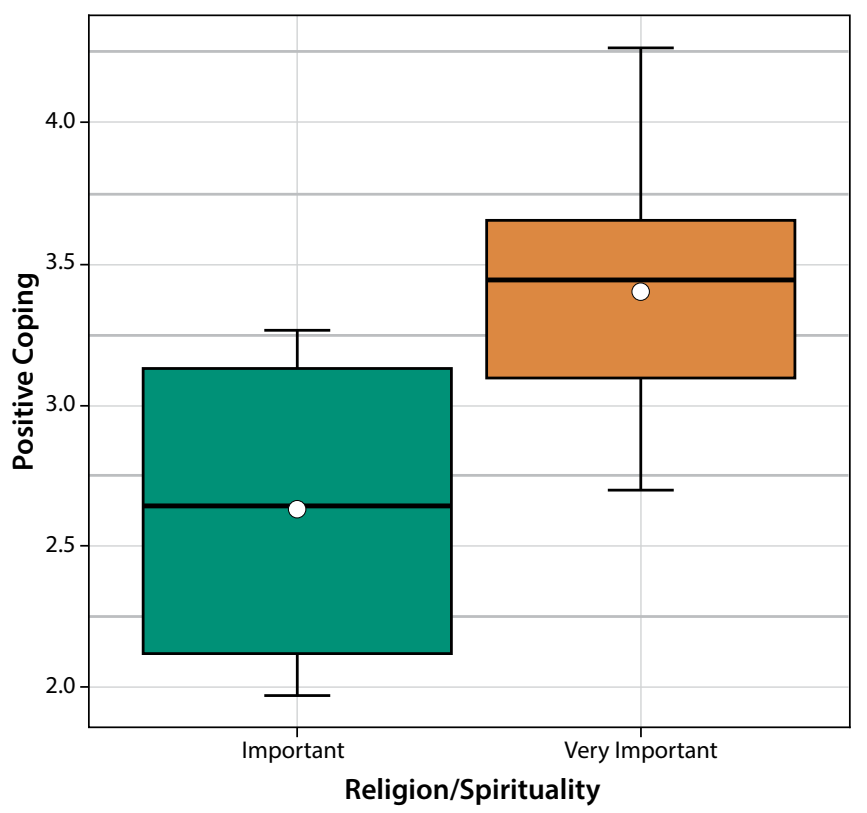

Figure 1 - Correlation between positive religious/spiritual coping and the importance given to spirituality/religiosity, Bauru, São Paulo, Brazil, 2020

\section{DISCUSSION}

In this study, it was evident that informal caregivers of children with cleft lip and/or palate predominantly used CREP. The benefits of this use are evident, constituting a source of comfort and hope for parents, in addition to favoring a better perception of quality of life, post-traumatic personal growth, stress reduction and quality of care provided ${ }^{(14,19)}$.

Parents, when faced with the birth of a child with cleft lip and/ or palate, associated with the syndrome, experience frustration with the dream of the idealized baby. In addition, these children often need to interrupt oral feeding due to dysphagia, requiring, in most cases, the use of a feeding tube. Thus, in addition to frustration, these parents may have other negative feelings, such as anxiety, fear of the unknown and stress ${ }^{(7)}$. In this context, the development of coping or coping strategies are essential, including those involving spiritual and/or religious aspects. 
These informal caregivers must be available and prepared in relation to the demand for specific care that the child needs ${ }^{(4)}$. Furthermore, they need to adapt to the reality they experience, requiring dedication and, at times, exclusive availability. In this sense, an investigation identified that caring parents experience overload, stress, anxiety, in addition to different degrees of depression ${ }^{(8-9)}$.

Despite this, with the benefits of using the feeding tube, such as weight gain and adequate child development, negative reactions and feelings are minimized, thus evidencing the use of situational coping or coping strategies ${ }^{(7)}$.

The prevalence of CREP use among caregivers in this study corroborates the literature, as the use of spiritual/religious beliefs is evidenced, especially among caregivers of pediatric patients ${ }^{(15,19)}$. In fact, a Brazilian study that investigated the use of SRC strategies in parents/caregivers of children with cancer showed that those who used the positive did not show depressive symptoms ${ }^{(15)}$.

It is known that CRE prevents or minimizes negative health outcomes for people. From this perspective, a study that evaluated the use of CREP and CREN associated with daytime salivary cortisol patterns in informal caregivers of patients with dementia revealed that those using positive strategies had decreased hormone production. The authors emphasize that cortisol is an important risk factor for cerebrovascular diseases ${ }^{(16)}$.

When experiencing an experience marked by suffering, the individual establishes a connection with spirituality, that is, when the caregiver seeks to understand the meaning of that suffering experienced, they begin to reflect on their own human condition, which is permeated with limitation and fragility. Thus, they act to overcome this situation ${ }^{(20)}$.

Thus, one of the resources used by informal caregivers of children is to realize that trust and positive thinking in God - that is, faith in divine power - is the best resource to be used, depositing hope and recognizing its limitations facing the disease ${ }^{(19)}$.

In fact, informal caregivers use religious/spiritual approaches to deal with their family members' health problems and the stress they experience ${ }^{(13)}$. Religious practices and the use of spirituality as coping strategies are frequently used in daily life by people to deal with problems and adverse life events.

This study showed that caregivers resorted to SRC with high intensity and with a predominance of positive strategies. The SRC Scale also allowed the analysis of secondary factor indices, which can inform how much the person uses positive and negative strategies, providing a detailed view of the set of strategies used by family members ${ }^{(11)}$.

In this sense, the factor analysis of the CREP dimension showed the factor "positive positioning before God" with the highest average in this dimension, indicating the high use of this strategy. This factor is defined as any behavior that seeks to look at the stressful stimulus in a beneficial way, seeking support in God and greater connection with $\mathrm{Him}$. In addition, it includes positive reassessments through God. These manifestations are revealed in attitudes such as singing, collaborating, pleading, approaching and/or relying on God; or even, in individual actions of belief in God's help ${ }^{(10-11)}$.

Thus, informal caregivers, in view of the demand for care for the child who has a cleft lip and/or palate, dysphagia and uses a feeding tube, rethink their actions, making sense of what is really important for the moment, that is, supporting themselves in God and provide quality care for the child, avoiding or minimizing complications.

In fact, mothers of children with special needs use religious and spiritual aspects as a way to accept and face the task of being a mother of a special child, interpreting the context as a gift from God, and that such a function should not be discussed, but accepted. With this, it reframes the situation and gathers strength to adapt to the care routine ${ }^{(21-23)}$.

In view of the above, the use of CRE provides hope, a feeling that makes the individual in adversity identify that there is a way out of suffering, resulting in courage to face the difficulties. Attachment to God involves a meaning, that is, the idea that God can work miracles and reverse the child's condition, even if it is chronic or serious ${ }^{(21,23-24)}$. Thus, the practice of religious/spiritual activities and their frequency are considered good indicators in the individuals' responses to different stressful situations ${ }^{(24-25)}$.

The data obtained in this study reveal that caregivers had a religion and practiced religious/spiritual activities with a certain frequency, in addition to considering religion and/or spirituality as something very important in their lives. For informal caregivers of pediatric patients, having and participating in a religion, in addition to praying to God to deal with the situation, promotes comfort, strength and guidance to deal with the demands of care $\mathrm{e}^{(19)}$.

Research that included 15 parents of children with cancer identified that religious activities are a means of achieving composure, having hope for the future and tolerating the difficulties and critical conditions related to the disease, as well as allowing acceptance of the child's difficult condition ${ }^{(26)}$.

Different studies have shown that religious involvement and church attendance have been widely used by caregivers, resulting in social support. Other benefits were revealed, including lesser perception of burden, depressive symptoms and better quality of care ${ }^{(13,27)}$.

The caregiver seeks, through religion and faith, to share their anxieties and weaknesses, converting them into support mechanisms to face the obstacles arising from the therapeutic routine ${ }^{(13,19)}$. Thus, religious practice significantly contributed to the use of CRE, since religious beliefs and practices arouse positive emotions in people $\mathrm{e}^{(21,28)}$.

On the other hand, caregivers who predominantly use the CREN have more depressive symptoms, anxiety, loneliness, increased psychological suffering, worse perception of quality of life, overload and even compromised health ${ }^{(17)}$. As an example, a Brazilian study that included 77 informal caregivers/parents of pediatric cancer patients confirmed that the use of negative CRE is associated with depressive symptoms ${ }^{(15)}$. Furthermore, an investigation carried out with informal caregivers of hospitalized elderly identified that negative SRC was associated with higher levels of depression ${ }^{(12)}$. In short, the influence of negative CRE on the worsening of mental health is evidenced.

In addition, the use of negative CRE is directly associated with the caregiver's health behavior patterns. In this sense, a study carried out with 256 caregivers evaluated the relationship between religious coping, positive and negative, and a general health risk index, identifying that the CREN influenced eating habits, being associated with a greater probability of weight gain and greater food restriction ${ }^{(17)}$. 
Another influencing variable refers to personal challenges, that is, the way in which the caregiver faces growth opportunities in the face of adversity. Along these lines, a study with Indian caregivers showed that the use of religious coping, especially positive strategies, was significantly related to post-traumatic growth. Thus, the use of efforts to find meaning and a positive position before God, within a spiritual framework, was related to the perception of positive changes in life. On the other hand, responses that reflected spiritual struggle-punishing God's revaluation and spiritual discontent-were linked to the reduced perception of post-traumatic growth ${ }^{(14)}$.

Although the correlation between the use of CREP and sociodemographic factors was not significant in this study, the fact that the participants were exclusively female and mothers may, in some way, have influenced the prevalent use of CREP. It is known that "female sex" influences both the experience of stress after the diagnosis of a pathology in the child and the parents' coping responses ${ }^{(7,22-23)}$. Thus, women are more likely than men to use $\mathrm{CRE}^{(29)}$.

Mothers experience stressful events and afflictions associated with the diagnosis of their children's disease more intensely, compared to fathers. In addition, mothers and fathers have differences regarding the role of caregivers of their children, which, in a way, shapes the coping reactions ${ }^{(3)}$.

A North American study carried out with parents of pediatric cancer patients identified that women were more likely than men to use CRE while dealing with the diagnosis of cancer in their child. This is due to the fact that women understand that they have greater responsibility during the treatment of their children's cancer, so they are more likely to engage in this coping model ${ }^{(29)}$.

Furthermore, in addition to gender and family level, the family environment and the coping mechanisms that parents use to adapt to the child's illness can be influenced by other sociodemographic characteristics ${ }^{(29)}$. It is noteworthy that most caregivers in this study had low socioeconomic status, and this variable can influence the use of coping ${ }^{(30)}$.

In short, the use of religion and spirituality have been presented as important sources of comfort and hope for caregivers in a challenging situation. In addition, this strategy helps in the acceptance of the child's chronic condition ${ }^{(7,19,21,23)}$, as in the case of dysphagic children, whose necessary care can cause overload and compromise the caregiver's quality of life, due to demands and difficulties linked to the act of caring.

\section{Study limitations}

The monocentric characteristic of this study as well as the specificity of the caregivers make it impossible to generalize the results. Thus, further investigations on SRC in different profiles of informal caregivers are needed to strengthen and expand the knowledge established here.

\section{Contributions to the field of Nursing}

The understanding of the caregiver's experience regarding the process of caring for a child with cleft lip and/or palate, dysphagia and using a feeding tube allowed us to realize that the use of CREP is an important coping mechanism: informal caregivers give new meaning to their experience until then negative, favoring spiritual growth and exerting greater control over their emotions. It is noteworthy that the quality of care provided depends a lot on the physical, psychological, emotional and spiritual health of the caregivers.

\section{CONCLUSIONS}

Informal caregivers of children with cleft lip and/or palate, dysphagic and using a feeding tube use the predominantly positive CRE as a way to face the demand for care imposed on them and the child's health condition. These findings show the possibility of including spirituality and/or religiosity as indicators of health and well-being.

\section{SUPPLEMENTARY MATERIAL}

Thesis result manuscript. Farinha, FT. Coping religioso/espiritual em cuidadores informais de crianças com fissura de lábio e/ou palato disfágicas [Internet]. 2020. Hospital for Rehabilitation of Craniofacial Anomalies, University of São Paulo. Available from: https://doi.org/10.11606/T.61.2020.tde-29032021-151641

\section{REFERENCES}

1. Setó-Salvia N, Stanier P. Genetics of cleft lip and/or cleft palate: association with other common anomalies. Eur J Med Genet. 2014;57(8):38193. https://doi.org/10.1016/j.ejmg.2014.04.003

2. Demoro CCSD, Fontes CMB, Trettene AS, Cianciarullo TI, Lazarini IM. Applicability of orem: training of caregiver of infant with Robin sequence. Rev Bras Enferm. 2018;71(suppl 3):1469-73. https://doi.org/10.1590/0034-7167-2016-0562

3. Hlongwa P, Rispel LC. "People look and ask lots of questions": caregivers' perceptions of healthcare provision and support for children born with cleft lip and palate. BMC Public Health. 2018;18(1):506. https://doi.org/10.1186/s12889-018-5421-x

4. Cassemiro LKDS, Trettene AS, Bom GC, Prado PC, Campos SMS, Lima RAG. Child care in enteral nutrition therapy: nursing technicians' theoretical and practical knowledge. Rev Enferm UERJ. 2019;27:e40917. http://doi.org/10.12957/reuerj.2019.40917

5. Araújo MGO, Dutra MOM, Freitas CCSL, Guedes TG, Souza FS, Baptista RS. Caring for the carer: quality of life and burden of female caregivers. Rev Bras Enferm. 2019;72(3):728-36. https://doi.org/10.1590/0034-7167-2018-0334

6. Simione M, Dartley AN, Cooper-Vince C, Martin V, Hartnick C, Taveras EM, et al. Family-Centered outcomes that matter most to parents: a pediatric feeding disorders qualitative study. J Pediatr Gastroenterol Nutr. 2020;71(2):270-5. https://doi.org/10.1097/ MPG.0000000000002741 
7. Banhara FL, Farinha FT, Bom GC, Razera APR, Tabaquim MLM, Trettene AS. Parental care for infants with feeding tube: psychosocial repercussions. Rev Bras Enferm. 2020;73(2):e20180360. https://doi.org/10.1590/0034-7167-2018-0360

8. Dantas KO, Neves RF, Ribeiro KSQS, Brito GEG, Batista MC. Repercussions on the family from the birth and care of children with multiple disabilities: a qualitative meta-synthesis. Cad Saude Publica. 2019;35(6):e001579. https://doi.org/10.1590/0102-311x00157918

9. Carvalho A, Araújo LJP, Veríssimo MT. When long-term care comes to an end: informal caregivers' perspectives on patient discharge. Rev Enferm Ref. 2019;4(22):107-15. http://doi.org/10.12707/RIV19023

10. Panzini RG, Bandeira DR. Coping (enfrentamento) religioso/espiritual. Arch Clin Psychiatry. 2007;34(suppl 1):126-35. https://doi.org/10.1590/ S0101-60832007000700016

11. Panzini RG, Bandeira DR. Escala de coping religioso-espiritual (escala cre): elaboração e validação de construto. Psicol Estud. 2005;10(3):50716. https://doi.org/10.1590/S1413-73722005000300019

12. Vitorino LM, Marins LS, Lucchetti ALG, Santos AEO, Cruz JP, Cortez PJO, et al. Spiritual/religious coping and depressive symptoms in informal caregivers of hospitalized older adults. Geriatr Nurs. 2018;39(1):48-53. https://doi.org/10.1016/j.gerinurse.2017.06.001

13. Azman A, Singh PSJ, Sulaiman J. Caregiver coping with the mentally ill: a qualitative study. J Ment Health. 2017;26(2):98-103. https://doi.org/ 10.3109/09638237.2015.1124395

14. Thombre A, Sherman AC, Simonton S. Religious coping and posttraumatic growth among family caregivers of cancer patients in India. J Psychosoc Oncol. 2010;28(2):173-88. https://doi.org/10.1080/07347330903570537

15. Vitorino LM, Lopes Jr LC, Oliveira GH, Tenaglia M, Brunheroto A, Cortez PJO, et al. Spiritual and religious coping and depression among family caregivers of pediatric cancer patients in Latin America. Psychooncology. 2018;27(8):1900-7. https://doi.org/10.1002/pon.4739

16. Merritt MM, McCallum TJ. Too much of a good thing?: positive religious coping predicts worse diurnal salivar cortisol patterns for overwhelmed African American female dementia family caregivers. Am J Geriatr Psychiatry. 2013;21(1):46-56. https://doi.org/10.1016/j. jagp.2012.10.006

17. Rabinowitz YG, Hartlaub MG, Saenz EC, Thompson LW, Gallagher-Thompson D. Is religious coping associated with cumulative health risk? An examination of religious coping styles and health behavior patterns in Alzheimer's dementia caregivers. J Relig Health. 2010;49(4):498512. https://doi.org/10.1007/s10943-009-9300-8

18. Panzini RG, Maganha C, Rocha NS, Bandeira DR, Fleck MP. Brazilian validation of the quality of life instrument/spirituality, religion and personal beliefs. Rev Saude Publica. 2011;45(1):153-65. http://doi.org/10.1590/S0034-89102011000100018

19. Alves DA, Silva LG, Delmondes GA, Lemos ICS, Kerntopf MR, Albuquerque GA. Cuidador de criança com câncer: religiosidade e espiritualidade como mecanismos de enfrentamento. Rev Cuidarte. 2016;7(2):1318-24. https://doi.org/10.15649/cuidarte.v7i2.336

20. Iseselo MK, Kajula L, Yahya-Malima KI. The psychosocial problems of families caring for relatives with mental illnesses and their coping strategies: a qualitative urban based study in Dar es Salaam, Tanzania. BMC Psychiatry. 2016;16:146. http://dx.doi.org/10.1186/ s12888-016-0857-y

21. Nageswaran S, Banks Q, Golden SL, Gower WA, King NMP. The role of religion and spirituality in caregiver decision-making about tracheostomy for children with medical complexity. J Health Care Chaplain. 2020;1-13. http://doi.org/10.1080/08854726.2020.1755812

22. Boehm TL, Carter EW. Facets of faith: spirituality, religiosity, and parents of individuals with intellectual disability. Intellect Dev Disabil. 2019;57(6):512-26. https://doi.org/10.1352/1934-9556-57.6.512

23. Costa ECL, Veloso RA, Feitosa JJM. Children with hydrocephalus: difficulties and mother's experience. Rev Interd [Internet]. 2013 [cited 2020 Aug 20];6(1):71-9. Available from: https://revistainterdisciplinar.uninovafapi.edu.br/index.php/revinter/article/view/17/pdf_9

24. Nimbalkar AS, Mungala BM, Khanna AK, Patil KH, Nimbalkar SM. Prayers and beliefs among relatives of children admitted in pediatrics wards. J Family Med Prim Care. 2019;8(3):1123-8. http://doi.org/10.4103/jfmpc.jfmpc_333_18

25. Rabelais $\mathrm{E}$, Jones NL, Ulrich CM, Deatrick JA. Meaning making and religious engagement among survivors of childhood brain tumors and their caregivers. Oncol Nurs Forum. 2019;46(2):170-84. http://doi.org/10.1188/19.0NF.170-184

26. Abdoljabbari M, Sheikhzakaryaee N, Atashzadeh-Shoorideh F. Taking refuge in spirituality, a main strategy of parents of children with cancer: a qualitative study. Asian Pac J Cancer Prev. 2018;19(9):2575-80. http://doi.org/10.22034/APJCP.2018.19.9.2575

27. Heo GJ, Koeske G. The role of religious coping and race in Alzheimer's disease caregiving. J Appl Gerontol. 2013;32(5):582-604. http://doi. org/10.1177/0733464811433484

28. Valcanti CC, Chaves ECL, Mesquita AC, Nogueira DA, Carvalho EC. Religious/spiritual coping in people with chronic kidney disease undergoing hemodialysis. Rev Esc Enferm USP. 2012;46(4):838-45. https://doi.org/10.1590/S0080-62342012000400008

29. Gage-Bouchard EA, Devine KA, Heckler CE. The relationship between socio-demographic characteristics, family environment, and caregiver coping in families of children with cancer. J Clin Psychol Med Settings. 2013;20(4):478-87. https://doi.org/10.1007/s10880-013-9362-3

30. Walke SC, Chandrasekaran V, Mayya SS. Caregiver burden among caregivers of mentally ill individuals and their coping mechanisms. J Neurosci Rural Pract. 2018;9(2):180-5. https://doi.org/10.4103/jnrp.jnrp_312_17 